\title{
Genetic Fidelity Study of the in vitro Regenerated Plants in LA Hybrids of Lilium cv. Pavia
}

\author{
Asmita $^{1 *}$, S.S. Sindhu ${ }^{1}$, M. Jayanthi' ${ }^{2}$, M.R. Dhiman ${ }^{1}$, M.K. Singh ${ }^{1}$ and Firoz Hossain ${ }^{3}$ \\ ${ }^{1}$ Division of Floriculture and Landscaping, Indian Agricultural Research Institute, \\ New Delhi - 110012, India \\ ${ }^{2}$ Division of Nematology, ${ }^{3}$ Division of Genetics, Indian Agricultural Research Institute, \\ New Delhi 110012, India \\ *Corresponding author
}

\begin{abstract}
A B S T R A C T
LA hybrids of Lilium are a high value ornamental flower having high demand in world cut flower market. The present experiment on Lilium cv. Pavia was conducted at Indian Agricultural Research Institute, New Delhi with an objective to regenerate plantlets from

Keywords

LA Lilium,

Micropropagation, Genetic fidelity, SSR marker

Article Info

Accepted:

08 August 2018

Available Online:

10 September 2018 bulb scale by tissue culture technique and further to check the genetic fidelity of the in vitro regenerates. Direct adventitious shoot bud formation was recorded without undergoing any callus phase which was induced from the base of the inner scale. Maximum shoot proliferation was observed with the treatment combination MS + 6-BAP $(2 \mathrm{mg} / \mathrm{l})+\mathrm{NAA}(0.1 \mathrm{mg} / \mathrm{l})$ when transferred to the proliferating media. 6-BAP was found to be more effective than kinetin in shoot multiplication and ranged from 5.68 to 15.80 . Twenty in vitro regenerates were randomly selected from the population raised from bulb scale for testing its genetic fidelity using SSR markers. Out of 18 markers screened, only 10 produced clear and reproducible bands. A total of 273 bands were generated from the 10 SSR markers in 21 in vitro regenerated plants. The number of scorable bands for each primer varied from 1 to 2 . No Polymorphism Information Content was recorded among the in vitro regenerates. Further, Dendrogram generated clearly indicated that there was no genetic variation among the in vitro plantlets raised from bulb scales. The banding profile of the micro raised plants was monomorphic and similar to the mother plant. Thus, bulb scale can be commercially used for mass multiplication of LA Lilium cv. Pavia.
\end{abstract}

\section{Introduction}

Lilium is a bulbous flower which has occupied top ten positions in the world cut flower market. The genus Lilium is a member of subclass Monocotyledonae and belongs to the family Liliaceae. It is native of cold and temperate region of the Northern Hemisphere (Anderson, 1986). Being an important monocot flower bulbs, it is also grown worldwide as pot plant and bedding plant. A wide range of flower shapes, sizes, colours and bulb morphologies are found under this genus. Most of the lilies make an excellent garden plant. A status of "Symbol of purity" has been awarded to this crop. Its bulbs are non-tunicated and composed of numerous modified leaves or scales and a compressed 
stem or basal plate. It can be propagated by both through sexual and asexual means; however it is commercially propagated by the vegetative means. Besides bulbs, lily can also be propagated by means of bulblets, bulbils, scaling and micro propagation. Propagation through bulb and bulblet is slow as compared to the micropropagation. Scaling technique is preferred to get commercial size of bulbs within 2-3 years. But, the number of bulblet produced per scale is highly influenced by the growing condition, propagating media and nature of the cultivars. Even by forcing the bulbs at different storage duration and temperature, only 3-5 bulblets per scale are produced which is not sufficient to meet the market demand.

For obtaining disease free quality planting material at high multiplication rate, tissue culture provides an alternative to the conventional method. Micropropagation is one of the viable approaches for large scale multiplication of bulblet within short period which is gradually becoming a multibillion dollar industry and now being practiced all over the world. Plant regeneration from various explants like leaves, stem nodes, filaments, pistils and scales (Yang et al., 2007; Mi and Liu, 2008) has been reported in lily. Takayama and Misawa (1983) used bulb scale as explant source in Lilium auratum, whereas Aguettaz et al., (1990) experimented on bulb scale of Lilium speciosum and reported direct plant regeneration. Bulb scale as explant source have also been used earlier in Lilium for in vitro multiplication by other worker (Liu and Yang, 2012; Wang et al., 2012; Qi et al., 2014; Vieira et al., 2015).

Till today, most of the protocols developed for large scale multiplication through different explant in mainly established for Asiatic and Oriental lily. No systematic experiment has been performed on multiplication of LA hybrid lily under in vitro condition and it need to be standardized because of the species specific response of the various genotypes in Lilium.

Since the main objective of the tissue culture is production of true to type plants. It is important to maintain genetic stability of the plantlets, however genetic variation namely, somaclonal variation occur during the process of in vitro culture between regenerates produced from same explant (Larkin and Scowcroft, 1981; Martins et al., 2004; Modgil et al., 2005). To test genetic fidelity of the in vitro regenerates, molecular marker has been utilized in tissue culture research (Debnath, 2012). Simple Sequence Repeats (SSR) marker is valuable and powerful tool used for analysis of genetic fidelity of in vitro regenerated plants. This marker is frequently multi-allelic and exhibit co-dominant segregation. Due to their highly polymorphic content and wide genome coverage, it is most suitable for assessment of genetic variation. Reproducibility of SSR or microsatellites is high and species specific. However, to date, SSR markers have not been used till date in Lilium for testing genetic fidelity of the in vitro regenerates. In the present work, the technique of SSR analysis was employed to evaluate clonal fidelity in LA Lilium hybrids. This is the first assessment of evaluating genetic variation using SSR marker in Lilium species.

\section{Materials and Methods}

\section{Plant material}

The present experiment was carried out at Central Tissue Culture Laboratory of the Discipline of Horticulture, Lal Bahadur Shastri Building, National Research Centre on Plant Biotechnology, Indian Agricultural Research Institute, New Delhi during 20152017. Whereas, molecular works were conducted at the ZTM \& BPD (Zonal Technology Management and Business 
Planning Development) unit, Indian Agricultural Research Institute, New Delhi during 2016-2017. Lilium LA Hybrid stock "Pavia" plants were grown in the greenhouse and bulb scales were excised. Inner scales were selected for the experiment removing outer scales. These inner scales were washed thoroughly under running tap water for half an hour, then pre-treated with Carbendazim $(0.2$ $\%)+$ Mancozeb $(0.2 \%)+8-\mathrm{HQC}(200 \mathrm{ppm})$ for 3.0 hours followed by surface sterilization with $70 \%$ ethanol for 30 second combined with $0.1 \% \mathrm{HgCl}_{2}$ for 7 minutes and finally rinsed with sterile water three times under laminar air flow.

The prepared explants of bulb scales were inoculated in the test tube containing MS medium (Murashige and Skoog, 1962) and 3\% (v/v) sucrose for adventitious shoot bud induction from bulb scale and then were transferred to different concentrations of 6BAP, kinetin and NAA for shoot proliferation. The $\mathrm{pH}$ of the medium was adjusted to 5.78 before addition of agar and autoclaved at $121^{\circ} \mathrm{C}$ for $20 \mathrm{~min}$.

\section{DNA extraction, PCR amplification condition and SSR analysis}

Twenty in vitro regenerated plants were randomly selected for the DNA extraction, from a population of 200 in vitro stock shoot cultures in addition to mother plant. $100 \mathrm{mg}$ young leaves were taken from each plant and extraction of the total genomic DNA was performed using kit as described by MacheryNagel (Duren, Germany). Nano Drop Spectrophotometer was used to assess the quality and quantity of DNA. Initially, optimum PCR conditions for the different SSR markers were standardized using various concentration of template DNA $(10,20,25,50$ $\mathrm{ng} / \mu \mathrm{l})$. The amplification was carried out using kit (one $\mathrm{PCR}^{\mathrm{TM}}$, Helix Bioscience, New Delhi, India) in a total volume of $20 \mu \mathrm{l}$ containing 25-30 ng of genomic DNA. Initially, 18 SSR markers were used for screening which were designed based on the previous report of Lilium SSR primers (Du et al., 2015). PCR amplification was performed using the programme: Initial denaturation at $95^{\circ} \mathrm{C}$ for 5 minutes followed by 35 cycles of 45 second denaturation at $95^{\circ} \mathrm{C}, 45$ second annealing at $60^{\circ} \mathrm{C}$ and 45 second extension at $72^{\circ} \mathrm{C}$ with a final extension at $72^{\circ} \mathrm{C}$ for 8 minutes. The amplified products were resolved on $3.5 \%$ agarose gel in TAE (1X) buffer stained with ethidium bromide and final picture was taken by Gel Documentation System (Alpha Innotech).

The size of the amplicons resolved was marked by comparing with 100 bp ladder (Thermo Scientific, India). Scoring of bands was done on the based on the presence or absence in the gel photographs. Homology of bands was based upon their migration distance in the gel. Similarity between pair's accession was calculated using The Jaccard's similarity coefficient $(\mathrm{J})$. The analysis was performed using Darwin 6 software package.

\section{Results and Discussion}

\section{Bulblet induction and plant regeneration}

Bulb scales inoculated in the basal MS medium along with 3\% sucrose started showing its response within one month after inoculation. Direct regeneration was observed without undergoing any callus phase. Adventitious shoot buds were induced from the base of the inner scale (Figure 1). The micro-shoots produced from the scale were transferred to the different proliferation media containing 6-BAP, kinetin and NAA (Table 1). The number of micro-shoots proliferated per shoot after one month of transferring in proliferation media ranged 5.68 to 15.80 . Maximum shoot proliferation was observed with the treatment combination MS + 6-BAP 
$(2 \mathrm{mg} / \mathrm{l})+\mathrm{NAA}(0.1 \mathrm{mg} / \mathrm{l})$ while, minimum number of shoot proliferation was observed in the MS medium devoid of any growth hormones. The type of cytokinin and its concentration, used for proliferation of shoot had pronounced effect on shoot multiplication. The present investigation showed that better proliferation was obtained with 6-BAP supplemented media than kinetin. Several studies have demonstrated that 6-BAP is a very effective promoter for shoot induction and plant multiplication in the family Liliaceae (Nhut, 1998; Ulrich et al., 1999). Kinetin was found to be less effective for shoot multiplication have also been reported by previous workers (Wawrosch et al., 2001; Han et al., 2004).

Liu and Yang (2012) obtained the highest number of shoots with $0.54 \mu \mathrm{M}$ TDZ and 0.54 $\mu \mathrm{M}$ NAA. Whereas, Naing et al., (2014) examined that the combination of $2.0 \mathrm{mg} / \mathrm{l}$ $\mathrm{NAA}$ and $1.0 \mathrm{mg} / \mathrm{l} \mathrm{BA}$ induced the more mean number of adventitious shoots with the highest shoot formation frequency in lily. Lilium cv. Pavia produced the maximum length of shoots with the treatment combination MS + BAP (4 $\mathrm{mg} / \mathrm{l})+\mathrm{NAA}(0.1 \mathrm{mg} / \mathrm{l})$ followed by $\mathrm{MS}+$ BAP $(2 \mathrm{mg} / \mathrm{l})+\mathrm{NAA}(0.1 \mathrm{mg} / \mathrm{l})$ and $\mathrm{MS}+$ BAP $(3 \mathrm{mg} / \mathrm{l})+\mathrm{NAA}(0.1 \mathrm{mg} / \mathrm{l})$ and was found to be statistically significant to the other treatment combination.

Maximum number of leaves was recorded (24.08) with the treatment combination MS + BAP $(2 \mathrm{mg} / \mathrm{l})+$ NAA $(0.1 \mathrm{mg} / \mathrm{l})$ followed by $\mathrm{MS}+\mathrm{BAP}(4 \mathrm{mg} / \mathrm{l})+\mathrm{NAA}(0.1 \mathrm{mg} / \mathrm{l})$. Rooting was performed in the $1 / 2$ strength MS medium supplied with different concentration of NAA (data not shown) after 4 sub-cultures at 4 weeks interval in shoot proliferation media. Rooted plantlets were hardened in medium containing sterilized peat and soil-rite mixture in glass jars covered with polypropylene caps where maximum survival percentage was recorded.

\section{Assessment of genetic fidelity by SSR marker}

A total of 18 SSR primers were used for initial screening where $10 \mathrm{SSR}$ primers produced clear and reproducible bands. The optimum annealing temperature for SSR markers varied from 55.3 to $61.4{ }^{\circ} \mathrm{C}$ (Table 2). 13 bands were produced from ten SSR primers with an average of 1.3 bands per primer. A total of 273 bands were generated from the 10 SSR markers in 21 in vitro regenerated plants. The observed allelic size for each primer was almost in the same range as described by $\mathrm{Du}$ et al., (2015) in the Lilium. The number of scorable bands for each primer varied from 1 to 2. No Polymorphism Information Content was recorded among the in vitro regenerates. The pair-wise value between the mother plant and the plantlets derived from different explants was recorded 1 based on similarity matrix of Jaccard's coefficient, indicating $100 \%$ similarity among clones. Further, Dendrogram generated clearly indicated that there was no variation among the in vitro plantlets raised from bulb scales.

The banding profile of the micro raised plants was monomorphic and similar to the mother plant (Figure 2 and 3). The source of explants, culture condition and the mode of regeneration mainly affects the genetic stability of the plantlets during micropropagation (Goto et al., 1998). Varshney et al., (2001) reported no genetic variation among the in vitro raised plants when used RAPD marker for the detection of genetic stability. Liu and Yang (2012) observed 4.2\% soma clonal variation using ISSR marker in Oriental lily microraised clones which developed via direct regeneration. Yin et al., (2013) used both AFLP and ISSR markers to check the genetic fidelity of the plantlets rose from leaf segments and recorded less than one percent polymorphism frequency in Oriental hybrid lily. 
Table.1 Effect of different proliferation media on micro-shoots proliferation in LA Lilium cv. Pavia

\begin{tabular}{|c|c|c|c|c|}
\hline S. No. & Treatment detail & $\begin{array}{l}\text { Number of } \\
\text { micro- } \\
\text { shoots } \\
\text { proliferated } \\
\text { per shoot }\end{array}$ & $\begin{array}{l}\text { Shoot } \\
\text { length } \\
\text { produced } \\
\text { per micro- } \\
\text { shoot }\end{array}$ & $\begin{array}{l}\text { Number of } \\
\text { leaves }\end{array}$ \\
\hline $\mathbf{T}_{0}$ & MS devoid of hormones (control) & $5.68^{d}$ & $2.80^{\mathrm{f}}$ & $10.08^{\mathrm{d}}$ \\
\hline$\overline{T_{1}}$ & $\mathrm{MS}+6-\mathrm{BAP}(1 \mathrm{mg} / \mathrm{l})+\mathrm{NAA}(0.1 \mathrm{mg} / \mathrm{l})$ & $11.76^{\mathrm{bc}}$ & $4.12^{\text {bcd }}$ & $12.16^{\mathrm{cd}}$ \\
\hline$\overline{T_{2}}$ & $\mathrm{MS}+6-\mathrm{BAP}(2 \mathrm{mg} / \mathrm{l})+\mathrm{NAA}(0.1 \mathrm{mg} / \mathrm{l})$ & $15.80^{\mathrm{a}}$ & $4.86^{\mathrm{b}}$ & $24.08^{\mathrm{a}}$ \\
\hline$\overline{T_{3}}$ & $\mathrm{MS}+6-\mathrm{BAP}(3 \mathrm{mg} / \mathrm{l})+\mathrm{NAA}(0.1 \mathrm{mg} / \mathrm{l})$ & $15.08^{\mathrm{ab}}$ & $4.56^{\mathrm{bc}}$ & $20.48^{\mathrm{ab}}$ \\
\hline$\overline{\mathbf{T}_{4}}$ & $\mathrm{MS}+6-\mathrm{BAP}(4 \mathrm{mg} / \mathrm{l})+\mathrm{NAA}(0.1 \mathrm{mg} / \mathrm{l})$ & $14.60^{\mathrm{abc}}$ & $5.68^{\mathrm{a}}$ & $20.72^{\mathrm{ab}}$ \\
\hline$\overline{T_{5}}$ & $\mathrm{MS}+6-\mathrm{BAP}(5 \mathrm{mg} / \mathrm{l})+\mathrm{NAA}(0.1 \mathrm{mg} / \mathrm{l})$ & $13.92^{\mathrm{abc}}$ & $3.20^{\mathrm{ef}}$ & $16.56^{\mathrm{bc}}$ \\
\hline $\mathbf{T}_{6}$ & MS + Kinetin $(1 \mathrm{mg} / \mathrm{l})+\mathrm{NAA}(0.1 \mathrm{mg} / \mathrm{l})$ & $11.20^{\mathrm{c}}$ & $3.26^{\mathrm{ef}}$ & $12.68^{\mathrm{cd}}$ \\
\hline$\overline{\mathbf{T}_{7}}$ & $\mathrm{MS}+\operatorname{Kinetin}(2 \mathrm{mg} / \mathrm{l})+\mathrm{NAA}(0.1 \mathrm{mg} / \mathrm{l})$ & $13.24^{\mathrm{abc}}$ & $3.72^{\text {de }}$ & $14.64^{\mathrm{bcd}}$ \\
\hline $\mathbf{T}_{8}$ & MS + Kinetin $(3 \mathrm{mg} / \mathrm{l})+\mathrm{NAA}(0.1 \mathrm{mg} / \mathrm{l})$ & $13.32^{\mathrm{abc}}$ & $3.92^{\text {cde }}$ & $15.96^{\mathrm{bcd}}$ \\
\hline$\overline{T_{9}}$ & MS + Kinetin $(4 \mathrm{mg} / \mathrm{l})+\mathrm{NAA}(0.1 \mathrm{mg} / \mathrm{l})$ & $13.00^{\mathrm{abc}}$ & $3.72^{\text {de }}$ & $14.92^{\mathrm{bcd}}$ \\
\hline $\mathbf{T}_{10}$ & $\mathrm{MS}+\operatorname{Kinetin}(5 \mathrm{mg} / \mathrm{l})+\mathrm{NAA}(0.1 \mathrm{mg} / \mathrm{l})$ & $13.04^{\mathrm{abc}}$ & $3.32^{\mathrm{def}}$ & $13.64^{\text {cd }}$ \\
\hline
\end{tabular}

The Duncan's test was used to distinguish differences between treatment means.

Means in the same column followed by different letters are significantly different at $P<0.05$.

Table.2 List of primers, their sequence, number and size of the amplified band generated by SSR primers in LA Lilium cv. Pavia

\begin{tabular}{|c|c|c|c|c|c|c|c|}
\hline $\begin{array}{l}\text { S. } \\
\text { No. }\end{array}$ & Primer code & Primer sequence & $\begin{array}{l}\text { Annealing } \\
\text { temperatu } \\
\text { re }\left({ }^{\circ} \mathrm{C}\right)\end{array}$ & $\begin{array}{l}\text { Number of } \\
\text { scorable } \\
\text { band per } \\
\text { primer }\end{array}$ & $\begin{array}{l}\text { Total } \\
\text { number } \\
\text { of bands } \\
\text { amplified }\end{array}$ & $\begin{array}{l}\text { Size } \\
\text { range } \\
\text { (bp) }\end{array}$ & PIC \\
\hline 1 & LS-ZJU04 & $\begin{array}{l}\text { F: CCGCGTGTCTTCACTCCTAT } \\
\text { R: GGGTGTCTTCCATCCTTTCA }\end{array}$ & $\begin{array}{l}59.4 \\
57.3\end{array}$ & 1 & 21 & $150-172$ & 0 \\
\hline 2 & LS-ZJU05 & $\begin{array}{l}\text { F: GGCTCGTATGAGGACAGCTC } \\
\text { R: TGCCCTAAACCCACAAAAT }\end{array}$ & $\begin{array}{l}61.4 \\
55.3\end{array}$ & 2 & 42 & $209-221$ & 0 \\
\hline 3 & LS-ZJU06 & $\begin{array}{l}\text { F: ACTTCTTCGCATCCCTCTCA } \\
\text { R: TCTGTTCGGAGGTCCCATAG }\end{array}$ & $\begin{array}{l}57.3 \\
59.3\end{array}$ & 2 & 42 & $263-293$ & 0 \\
\hline 4 & LS-ZJU07 & $\begin{array}{l}\text { F: TGATCTCTGAGCTCCCCACT } \\
\text { R: TGAGAATTGGATCAGGCGTT }\end{array}$ & $\begin{array}{l}59.4 \\
55.3\end{array}$ & 1 & 21 & $126-160$ & 0 \\
\hline 5 & ILS-ZJU08 & $\begin{array}{l}\text { F: CATCAGCAACAACAAACCCA } \\
\text { R: CTATGATTATAAGGCCGCCG }\end{array}$ & $\begin{array}{l}55.3 \\
57.3\end{array}$ & 1 & 21 & $145-157$ & 0 \\
\hline 6 & LS-ZJU09 & $\begin{array}{l}\text { F: AAGTCAGCAGCAACAGCAGA } \\
\text { R: CAGGTAAAAATCCGCCAGAA }\end{array}$ & $\begin{array}{l}57.3 \\
55.3\end{array}$ & 1 & 21 & $224-266$ & 0 \\
\hline 7 & LS-ZJU10 & $\begin{array}{l}\text { F: GTGTCGATGAAGACAGCGAA } \\
\text { R: ACCAAACCTGAAAATCTGCG }\end{array}$ & $\begin{array}{l}57.3 \\
55.3\end{array}$ & 1 & 21 & $170-188$ & 0 \\
\hline 8 & LS-ZJU52 & $\begin{array}{l}\text { F: GAGCTCCTCTCCCTCCAGTT } \\
\text { R: CCCTCTCCGTAGCTTTTCCT }\end{array}$ & $\begin{array}{l}61.4 \\
59.4\end{array}$ & 1 & 21 & $232-244$ & 0 \\
\hline 9 & LS-ZJU53 & $\begin{array}{l}\text { F: GAGAAGACACCGAAACCTCG } \\
\text { R: TGAAGAACCAGCACGAACTGT }\end{array}$ & $\begin{array}{l}59.4 \\
57.9\end{array}$ & 1 & 21 & 273-306 & 0 \\
\hline 10 & LS-ZJU54 & $\begin{array}{l}\text { F: TGGCACATCAGATGGTGAAT } \\
\text { R: GGCCTCGATGACAAACCTTA }\end{array}$ & $\begin{array}{l}55.3 \\
57.3\end{array}$ & 2 & 42 & $206-230$ & 0 \\
\hline Total & & & & 13 & 273 & & 0 \\
\hline
\end{tabular}


Fig.1 Adventitious shoot bud induction and plant regeneration from bulb scale in LA Hybrids of Lilium cv. Pavia, (a) Adventitious shoot bud, (b) Regeneration from adventitious shoot, (c \& d)

Shoot proliferation, (e) Rooted plant, (f) Hardened plant.

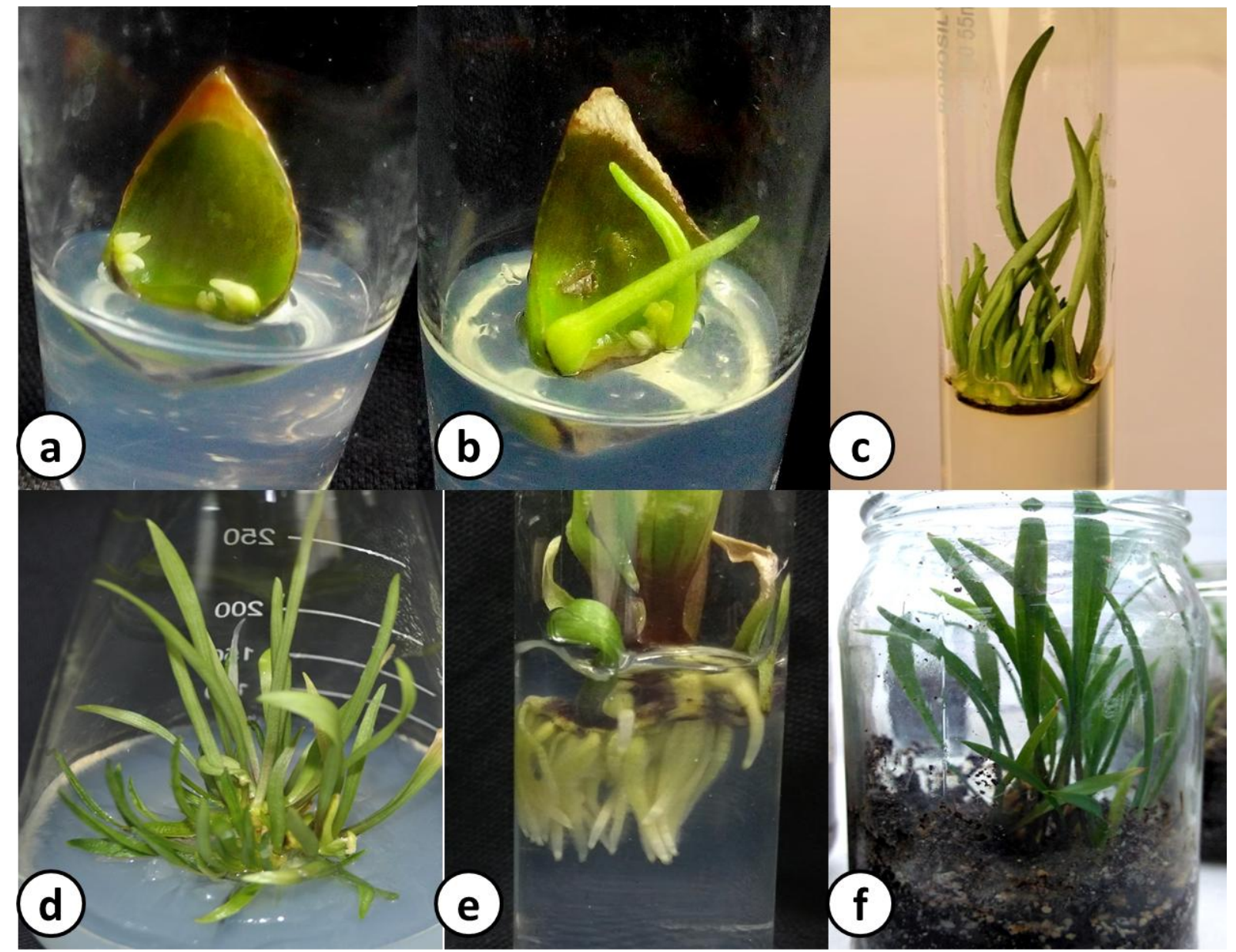

Fig.2 PCR amplification product obtained with SSR- LS-ZJU07 primer. Lane L represents 100 bp ladder, Lane M represents the mother plant, Lane 1-20 represnts in vitro plantlets derived from bulb scale explant in Lilium cv. Pavia.

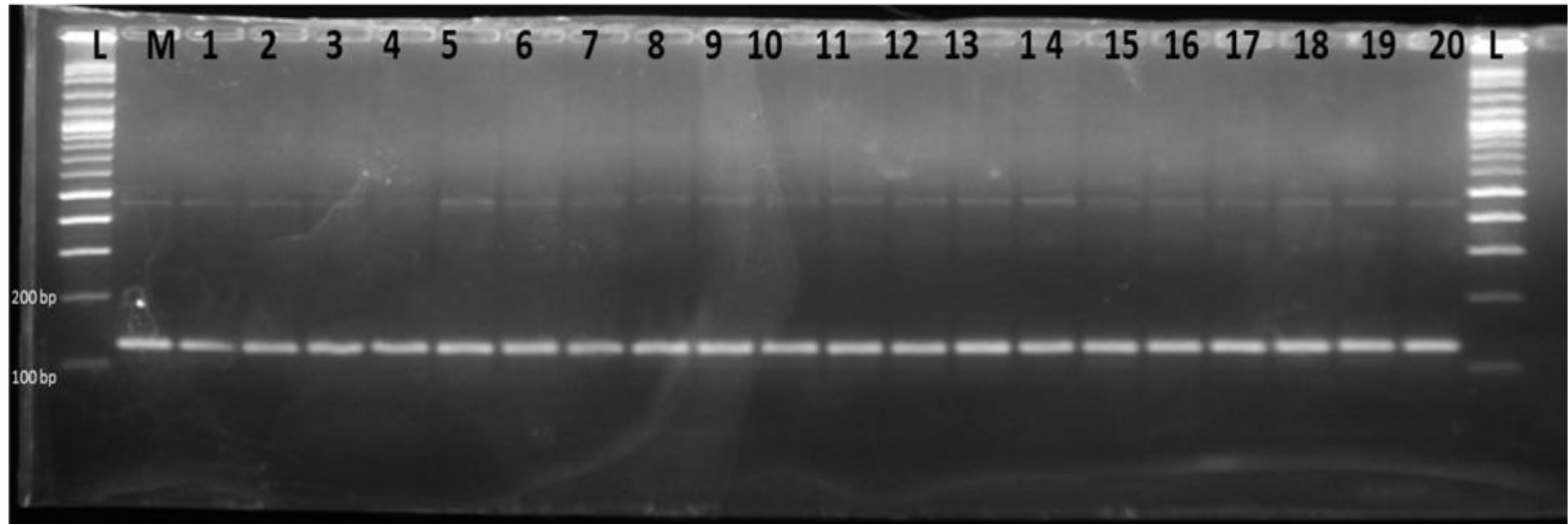


Fig.3 PCR amplification product obtained with SSR- LS-ZJU54 primer. Lane L represents 100 bp ladder, Lane M represents the mother plant, Lane 1-20 represents in vitro plantlets derived from bulb scale explant in Lilium cv. Pavia.

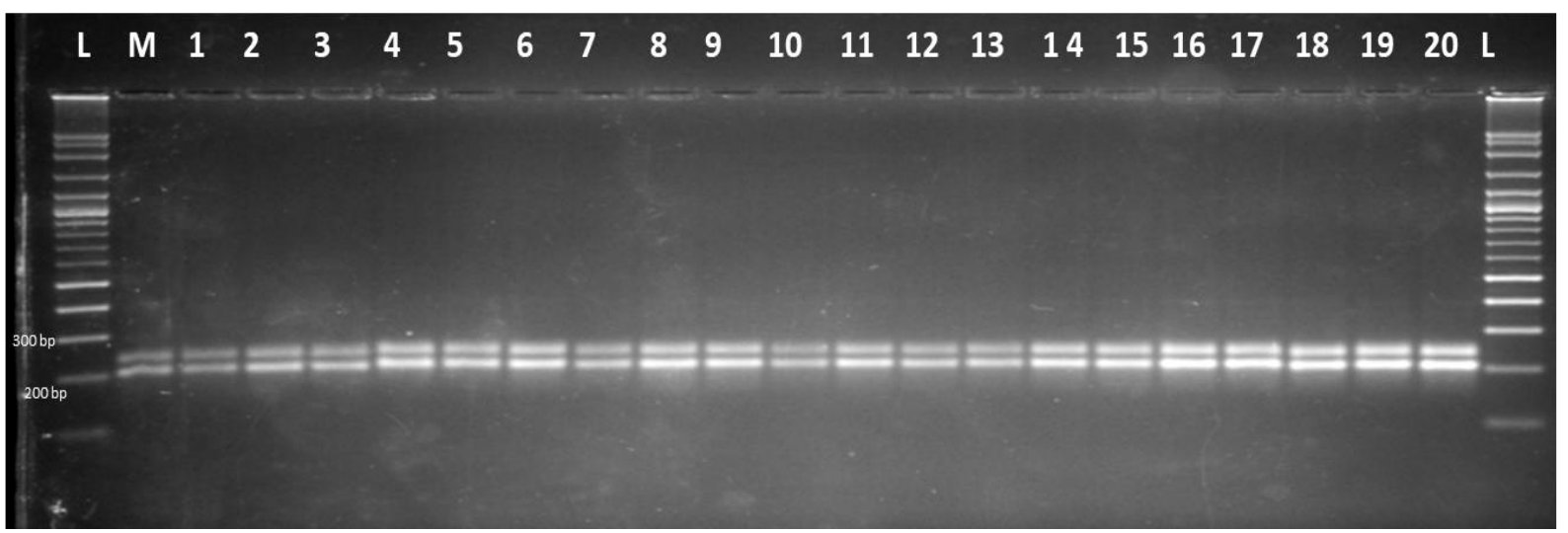

Earlier RAPD and ISSR were used to detect clonal fidelity of the in vitro raised clones in many plant species (Martin et al., 2004). But, now a day, use of SSR marker is recommended as compared to other markers. Being species specific, SSR marker allows best detection of the variability among the regenerates as compared to other PCR based markers. SSR markers are simple, consistent and highly efficient in evaluating the genetic diversity and phylogenetic studies (Kalia et al., 2011; Du et al., 2015). In the present study of in vitro regeneration from bulb scale soma clonal variation was detected by DNA based SSR primers. Hence, bulb scale explant can be successfully used for commercial multiplication of LA hybrids of Lilium with no or less risk of genetic variability. Plants derived from well-developed meristem region generally show lowest tendency of genetic variation among clones (Joshi and Dhawan, 2007). But, it has also been reported in many plant species that even plants derived from organized meristems are not always true to the type (Devarumath et al., 2002). The higher concentration of synthetic plant growth regulator and increasing numbers of subcultures increase the chances of soma clonal variation in micropropagated plants (Bairu et al., 2011). Hence, it becomes essential to regularly check the genetic purity of the micro-raised plants in order to produce clonally uniform progeny. In the present study, plantlets were derived from the sprouting of dormant buds situated at the base of bulb scales where no genetic variation was recorded among clones. These findings support the fact that a meristem-based micropropagation system is much more stable genetically than those in which regeneration occurs via the callus phase.

\section{Acknowledgements}

The authors are grateful to the Dr. Rajkumar Uttamrao Zunjare and Dr. Rashmi Chhabra for valuable suggestion during research work and University Grants Commission, Ministry of Human Resource Development, and Government of India for the financial assistance.

\section{Conflict of interest}

The authors have no conflict of interest.

\section{References}

Aguettaz, P. Paffen, A. Delvallee, I. Van der Linde, P. and De Klerk, G. J., 1990. The 
development of dormancy in bulblets of Liliumspeciosum generated in vitro. Plant Cell, Tissue Organ Culture, 22(3): 167-172.

Anderson, N. O., 1986. The distribution of the genus Lilium with reference to its evaluation. Lily Yearbook North Am. Lily Soc., 42: 1-18.

Bairu, M. W. Aremu, A. O. and Van Staden, J., 2011, Somaclonal variation in plants: causes and detection methods. Plant Growth Regulation, 63(2): 147-173.

Debnath, S. C., 2012, Molecular markers for genetic fidelity during in vitro propagation of horticultural crops. Acta Hort., 459-465.

Devarumath, R. Nandy, S. Rani, V. Marimuthu, S. Muraleedharan, N. and Raina, S., 2002, RAPD, ISSR and RFLP fingerprints as useful markers to evaluate genetic integrity of micropropagated plants of three diploid and triploid elite tea clones representing Camellia sinensis (China type) and $C$. assamica (Assam-India type). Plant Cell Reports, 21(2): 166-173.

Du, F. Jiang, J. Jia, H. Zhao, X. Y. Wang, W. H. Gao, Q. K. and Xia, Y. P., 2015, Selection of generally applicable SSR markers for evaluation of genetic diversity and identity in Lilium. Biochem. Syst. Ecol., 61: 278285.

Goto, S. Thakur, R. C. and Ishii, K., 1998, Determination of genetic stability in long-term micropropagated shoots of Pinusthunbergii Parl. using RAPD markers. Plant Cell Rep., 18(3-4): 193197.

Han, B. H. Yu, H. J. Yae, B. W. and Paek, K. Y., 2004. In vitro micropropagation of Liliumlongiflorum 'Georgia' by shoot formation as influenced by addition of liquid medium. Scientia Horticulturae, 103(1): 39-49.
Joshi, P and Dhawan, V., 2007, Assessment of genetic fidelity of micropropagated Swertiachirayita plantlets by ISSR marker assay. Biol. Plant., 51(1): 22-26.

Kalia, R. K. Rai, M. K. Kalia, S. Singh, R. and Dhawan, A. K., 2011, Microsatelite markers: an overview of the recent progress in plants. Euphytica, 177(3): 309-334.

Larkin, P. J. and Scowcroft, W. R., 1981, Somaclonal variation - a novel source of variability from cell cultures for plant improvement. Theor. App. Genet., 60(4): 197-214.

Liu, X. M. and Yang, G. C., 2012, Adventitious shoot regeneration of oriental lily (Lilium orientalis) and genetic stability evaluation based on ISSR marker variation. In Vitro Cell. Dev. Biol. Plant., 48(2): 172-179.

Martins, M. Sarmento, D. and Oliveira, M. M., 2004, Genetic stability of micropropagated almond plantlets as assessed by RAPD and ISSR markers. Plant Cell Rep., 23(7): 492-496.

Mi, Z. W. and Liu, Q. L., 2008, Plantlet regeneration from different explants of lily. Acta Hortic., 766: 143-147.

Modgil, M. Mahajan, K. Chakrabarti, S. K. Sharma, D. R. and Sobti, R. C., 2005, Molecular analysis of genetic stability in micropropagated apple rootstock MM106. Sci. Hortic., 104(2): 151-160.

Murashige, T. and Skoog, F., 1962, A revised medium for rapid growth and bioassays with tobacco cultures. Physiol. Plant., 15(3): 473-497.

Naing, A. H. Yun, H. Lucidos, J. Hwang, Y. J. Kim, C. K. Ahn, B. J. and Lim, K. B., 2014, Plant regeneration through various explants of Lilium longiflorum hybrid "Bright Tower" and determination of ploidy level of regenerated plants. Plant Biosystems, 148(2): 191-199. 
Nhut, D. T., 1998, Micropropagation of lily (Lilium Iongiflorum). Plant Cell Rep., 17: 913-916.

Qi, Y. Du, L. Quan, Y. Tian, F. Liu, Y. and Wang, Y., 2014, Agrobacterium mediated transformation of embryogenic cell suspension cultures and plant regeneration in Lilium tenuifolium oriental $\times$ trumpet 'Robina'. Acta Physiologiae Plantarum, 36(8): 2047-2057.

Takayama, S. and Misawa, M., 1983, A scheme for mass propagation of Lilium in vitro. Scientia Horticulturae, 18(4): 353-362.

UIrich, M. R. Davies, F. T. Koh, Y. C. Duray, S. A. and Egilla, J. N., 1999, Micropropagation of Crinum 'Ellen Bosanquet' by triscales. Sci. Hortic., 82: 95-102.

Varshney, A. Lakshmikumaran, M. Srivastava, P. S. and Dhawan, V., 2001, Establishment of genetic fidelity of in vitro raised Lillium bulblets through
RAPD markers. In Vitro Cell.Dev. Biol. Plant, 37(2): 227-231.

Vieira, P. Wantoch, S. Lilley, C. J. Chitwood, D. J. Atkinson, H. J. and Kamo, K., 2015, Expression of a cystatin transgene can confer resistance to root lesion nematodes in Lilium longiflorum cv. 'Nellie White'. Transgenic Research, 24(3): 421-432.

Wang, Q. M. Gao, F. Z. Gao, X. Zou, F. Y. Sui, X. Wang, M. Hui, Y. J. and Wang, L., 2012, Regeneration of Cliviaminiata and assessment of clonal fidelity of plantlets. Plant Cell, Tissue Organ Cult., 109(2): 191-200.

Wawrosch, C. Malla, P. R. and Kopp, B., 2001, Clonal propagation of Lilium nepalense D. Don, a threatened medicinal plant of Nepal. Plant Cell Reports, 20(4): 285-288.

Yang, X. Q. Wang, S. F. Yang, R. Sun, X. M. Gui, T. Q. and Sun, M., 2007, Bulblet Cluster Induction and Rapid Propagation of Lilium sulphureum Baker. J. Henan Agricul. Sci., 3: 26-30.

\section{How to cite this article:}

Asmita, S.S. Sindhu, M. Jayanthi, M.R. Dhiman, M.K. Singh and Firoz Hossain. 2018. Genetic Fidelity Study of the in vitro Regenerated Plants in LA Hybrids of Lilium cv. Pavia. Int.J.Curr.Microbiol.App.Sci. 7(09): 1223-1231. doi: https://doi.org/10.20546/ijcmas.2018.709.146 